\title{
Digital Divide: Issues Facing Adult Learners
}

\author{
Ramesh Rao \\ Department of Economics \\ Faculty of Economics and Administration \\ University of Malaya \\ 50603 Kuala Lumpur, Malaysia \\ Tel: 60-17-8792159Ｅ-mail: rameshdivan@yahoo.com
}

\begin{abstract}
Technology had enabled many adult to pursue their education. However, technology changes in terms of type and accessing had caused "digital divide" (DD) to exist among students of all ages. In this paper, issues which should be incorporated in measuring digital divide for adult learners are discussed. The issues which are discussed in this paper are age, gender and income. Why these issues should be included in evaluating DD are examined.
\end{abstract}

Keywords: Digital divide, Adult learners

\section{Introduction}

Among the educational resource which is gaining importance is technology (Anderson, et.al (2001). The evolution of technology had changed the way teaching and learning is carried out. The ever changing technology (as shown in Table 1) could create an imbalance in a society. Researches had shown that, developments in technology had reduced employment opportunities for older workers (Aubert, Caroli \& Muriel, 2006). Although the role of technology in influencing the learning and teaching process in education is disputed but its presence is necessary. This makes it important that technology should be made available to every student.

In the case of school students, it would be the responsibility of the authorities in providing the technology to every student. On the contrary, for adult learners the onus is on the learner himself and not others. Adult learners are people who have finished their secondary education and pursuing their education. Many adults pursue education because they believe it will enhance their employability and eventually increase earnings (Wiseman, 1987). Innovations and advancement in technology had enabled many working adults to pursue their education. Computer assisted learning environment has helped adult learners in coping with their education (Thompson \& Savenye, 2007).

However, the advancement in ICT had resulted in a digital divide among the students. Digital divide (DD) is also known as digital equity (DE) (Becker, 2006). Digital divide is defined as the different use of technology in education based in ethnicity and socioeconomic status, while DE refers to the activity of ensuring that all students have the same amount of access to information and technology for learning (Judge, Puckett \& Cabuk, 2004). The term DD began to appear in American vocabulary back in the 1990's (Light, 2001). If the DD is big among the students of an institution, it could lead to an imbalance and unfair scenario in student's performance.

There are some researches done in evaluating DD among the adult learners. Access and usage of technology especially internet had spurred many researches in measuring DD for students. The role and effect of computer usage in the learning process for adult learners depends on the extent of DD (Gorard, 2003). In this paper, issues which must be incorporated in measuring DD for adult learners are explored. Issues faced by adult learners and how it might influence DD are discussed in this paper.

\section{Issues In Digital Equity}

\subsection{Age}

Research in cognitive sciences had shown that there is a relationship between age and technology adoption in learning. Younger people are more receptive in adapting changes in the way they learn compared with older people (Bosma et al., 2003). Technology assimilation among older people is slower compared to younger people (Morris \& Venkatesh, 2000). A study in Canada on teaching Mathematics using computer found that adult learners' academic performance was better when computers and teachers were used simultaneously. On the other hand, comparing with school children, teacher's 
role in the teaching and learning process is required less (for children) compared for adult learners (Li \& Edmonds, 2005). Since the age of adult learners varies, any study on the DD should consider age as a factor.

\subsection{Gender}

Attitudes and perceptiveness of technology is different between the sexes. While males perceive technology positively and easy, female thinks it as otherwise (Menard-Warwick \& Dabach, 2004, Bain \& Rice, 2007; McKinney et.al, 2008). Lack of interest and participation of girls and women in technology had prompted the formation of AAUW Educational Foundation Commission on Technology, Gender, and Teacher Education in 1998 (AAUW, 2000).

Many countries are facing a gender imbalance in student enrollment. As shown in Figure 1, many ASEAN countries are having higher enrollment of girls than boys at tertiary level enrollment. Many studies on DD, does not take whether the results would be different if gender was included in the computation of the value. Many adult learners are enrolled in tertiary level programs. Since the probability of more females than male students is higher, any measurement on DD should take note of this.

\subsection{Income}

There is a correlation between income and technology (Frank, 1995). Since technology is not a public good, owning a computer itself will consume some of the income (Kalyanpur \& Kirmani, 2005). Technology utilization usage especially internet and broadband facilities will require an individual to bear the expenses incurred. Although this sum could be minimal but when the person's income is low, it could be a significant portion.

Table 2 shows the correlation between computers per 1000 with the household income for selected countries. In countries where household income is low, computer ownership is highly significant. But in developed countries such as Belgium and Sweden, computer ownership does not really depend on household income. This could be because the amount of income, in terms of percentage, devoted for computer is small in developed countries compared in developing or undeveloped countries.

Since most adult learners are working, thus their income level could hinder their use technology. The amount a person could allocate or spend on technology access depends on the amount of his/her disposable income. When a person's disposable income is high and the cost of accessing technology i.e internet, is low, thus proportionately it is low. Ultimately the cost of accessing technology would not jeopardize his/her consumption on other goods. On the other hand, if the proportion is high it would force the adult learner to do some sacrifice in consuming or purchasing other goods. Although one could argue, that being a student, priority should be given to education, but being a human being who are subjected to needs and wants, this could be easier said than done.

Since finance is an influencing factor in human's daily life, thus income of adult learners who are working should be considered when discussing DD. "Income's" influences in DD would be higher if the cost of accessing technology is high proportionately to income.

\subsection{Language Mastery}

English is the main language used in internet (See Table 3). Most of the materials in the internet use English as the medium of instruction. This hinders some people from using the internet. Even in countries where there is internet facilities, proficiency in English could discourage some from accessing the internet. As shown in Table 4, among the ASEAN countries, only Filipinos uses English when online. Countries such as Indonesia and Malaysia, non-English language are more widely used.

Thus, adult learners in these countries could face some difficulties when accessing the internet. Since most of the materials are not in their familiar language, this could increase the inequity in accessing the technology. Therefore when evaluating DD, language mastery especially English should be taken as a factor.

\section{Conclusion}

By taking into consideration factors that influence DD among adult learners, it would be possible for curriculum designers to incorporate the findings. Adult learners should be given all the necessary encouragement in pursuing their education. By taking into consideration factors affecting DD adult learners, methods on evaluating them could be designed in such a way which would be beneficial to both the learner and teacher. However this does not mean that different standards should be set for adult learners with various characteristics but concessions should be thought of. For example, a more flexible time of completing a study programme should be given to adult learners with different characteristics.

\section{References}

AAUW. (2000). Educating Girls in the New Computer Age By the, Gender, and Teacher Education. Washington: AAUW Educational Foundation Commission on Technology. 
Anderson, L., Briggs, A. R., \& Burton, N. (2001). Managing Finance, Resources and Stakeholders in Education: Paul Chapman Publishing.

Aubert, P., Caroli, E., \& Roger, M. (2006). New technologies, organisation and age: firm-level evidence. Economic Journal, 116(509), 73-94.

Bain, C. D., \& Rice, M. L. (2007). The Influence of Gender on Attitudes, Perceptions, and Uses of Technology. Journal of Research on Technology in Education, 39(2), 119-132.

Becker, J. D. (2006). Digital Equity in Education: A Multilevel Examination of Differences in and Relationships between Computer Access, Computer Use and State-level Technology Policies. Education Policy Analysis Archives, 15(3), 1-36.

Bosma, H., Boxtel, M. P. J. V., Ponds, R. W. H. M., Houx, P. J. H., \& Jolles, J. (2003). Education and age related cognitive decline: the contribution of mental workload. Educational Gerontology, 29(2), 165-173.

Frank, J. (1995). Preparing for the information highway: Information technology in Canadian households. Canadian Social Trends, (38), 2-7.

Global reach. (2006). Retrieved 11 May 2008, from http://global-reach.biz/globstats/index.php3

Gorard, S. (2003). Adult Learners in Wales: Trajectories and Technologies. Innovations in Education and Teaching International, 40(4), 395-403.

Gorski, P. (2005). Education equity and the digital divide. AACE Journal, 13(1), 3-45.

Judge, S., Puckett, K., \& Cabuk, B. (2004). Digital Equity: New Findings from the Early Childhood Longitudinal Study. Journal of Research on Technology in Education, 36(4), 383-397.

Kalyanpur, M., \& Kirmani, M. H. (2005). Diversity and Technology: Classroom Implications of the Digital Divide. Journal of Special Education Technology, 20(4), 9-18.

Li, Q., \& Edmonds, K. A. (2005). Mathematics and At-Risk Adult Learners: Would Technology Help? Journal of Research on Technology in Education, 38(2), 143-166.

Light, J. S. (2001). Rethinking the digital divide. Harvard Educational Review, 71(4), 709-735.

Mar, N. Y. (2004). Utilizing Information and Communication Technologies to Achieve Lifelong Education for All: A Case Study of Myanmar. Educational Research for Policy and Practice, 3(2), 141-166.

McKinney, V. R., Wilson, D. D., Brooks, N., O’Leary-Kelly, A., \& Hardgrave, B. (2008). Women and Men in the IT Profession. Communications of the ACM, 51(2), 81-84.

Menard-Warwick, J., \& Dabach, D. B. (2004). "In a little while I could be in front": Social mobility, class, and gender in the computer practices of two Mexicano families. Journal of Adolescent \& Adult Literacy, 47(5), 380-390.

Morris, M. G., \& Venkatesh, V. (2000). Age Differences In Technology Adoption Decisions: Implications For A Changing Work Force. Personnel Psychology, 53(2), 375-403.

Thompson, E. W., \& Savenye, W. C. (2007). Adult Learner Participation in an Online Degree Program: A program-level study of voluntary computer-mediated communication. Distance Education, 28(3), 299-312.

Wiseman, J. (1987). Public Finance in education. Oxford: Pergamon Press.

Table 1. ICT's and their potential for education

\begin{tabular}{|l|l|l|l|}
\hline Technology & Outreach & Flexibility & Interactivity \\
\hline Radio & High & Limited & Limited \\
\hline Television & High & Limited & Limited \\
\hline Video & Low & Limited & Limited \\
\hline Personnel Computers & Low & High & High \\
\hline Internet & Highest & High & Highest \\
\hline
\end{tabular}

Source: Adapted From Mar, 2004 
Table 2. Correlation between computer ownership and household income

\begin{tabular}{|l|l|}
\hline Country & Significance Level \\
\hline Austria & $\sqrt{ }$ \\
\hline Belgium & $\mathrm{X}$ \\
\hline Brazil & $\sqrt{ }$ \\
\hline Chile & $\sqrt{ }$ \\
\hline Denmark & $\mathrm{X}$ \\
\hline India & $\sqrt{ }$ \\
\hline Indonesia & $\sqrt{ }$ \\
\hline Malaysia & $\sqrt{ }$ \\
\hline Philippines & $\sqrt{ }$ \\
\hline Singapore & $\mathrm{X}$ \\
\hline Sweden & $\mathrm{X}$ \\
\hline
\end{tabular}

Source: Computed by author based on data provided by UN

Note: $\quad \sqrt{ }=$ Significant

$\mathrm{X}=$ Not significant

Table 3. The 10 Most Highly Represented Languages on Web Pages (2000)

\begin{tabular}{|l|c|c|}
\hline Language & Web Pages (in millions) & Percent of total \\
\hline English & 241.250 & 68.39 \\
\hline Japanese & 18.336 & 5.85 \\
\hline German & 18.070 & 5.77 \\
\hline Chinese & 12.114 & 3.87 \\
\hline French & 9.263 & 2.96 \\
\hline Spanish & 7.573 & 2.42 \\
\hline Russian & 5.901 & 1.88 \\
\hline Italian & 4.883 & 1.56 \\
\hline Portuguese & 4.291 & 1.37 \\
\hline Korean & 4.046 & 1.29 \\
\hline
\end{tabular}

Source: Gorski, 2005.

Table 4. Number of people online in each language (2004)

\begin{tabular}{|l|c|c|c|c|c|}
\hline \multirow{2}{*}{ Country } & \multicolumn{4}{|c|}{ Language Analysis (in millions) } & \multirow{2}{*}{ Total } \\
\cline { 2 - 5 } & English & Chinese & Malay & Thai & \\
\hline Indonesia & & & 8.1 & & 8.1 \\
\hline Malaysia & 0.2 & 2.9 & 5.8 & & 8.7 \\
\hline Philippines & 3.5 & & & & 3.5 \\
\hline Singapore & 0.2 & 2.1 & 0.3 & & 2.6 \\
\hline Thailand & & & & 7 & 7 \\
\hline
\end{tabular}

Source: Global Reach, 2006 


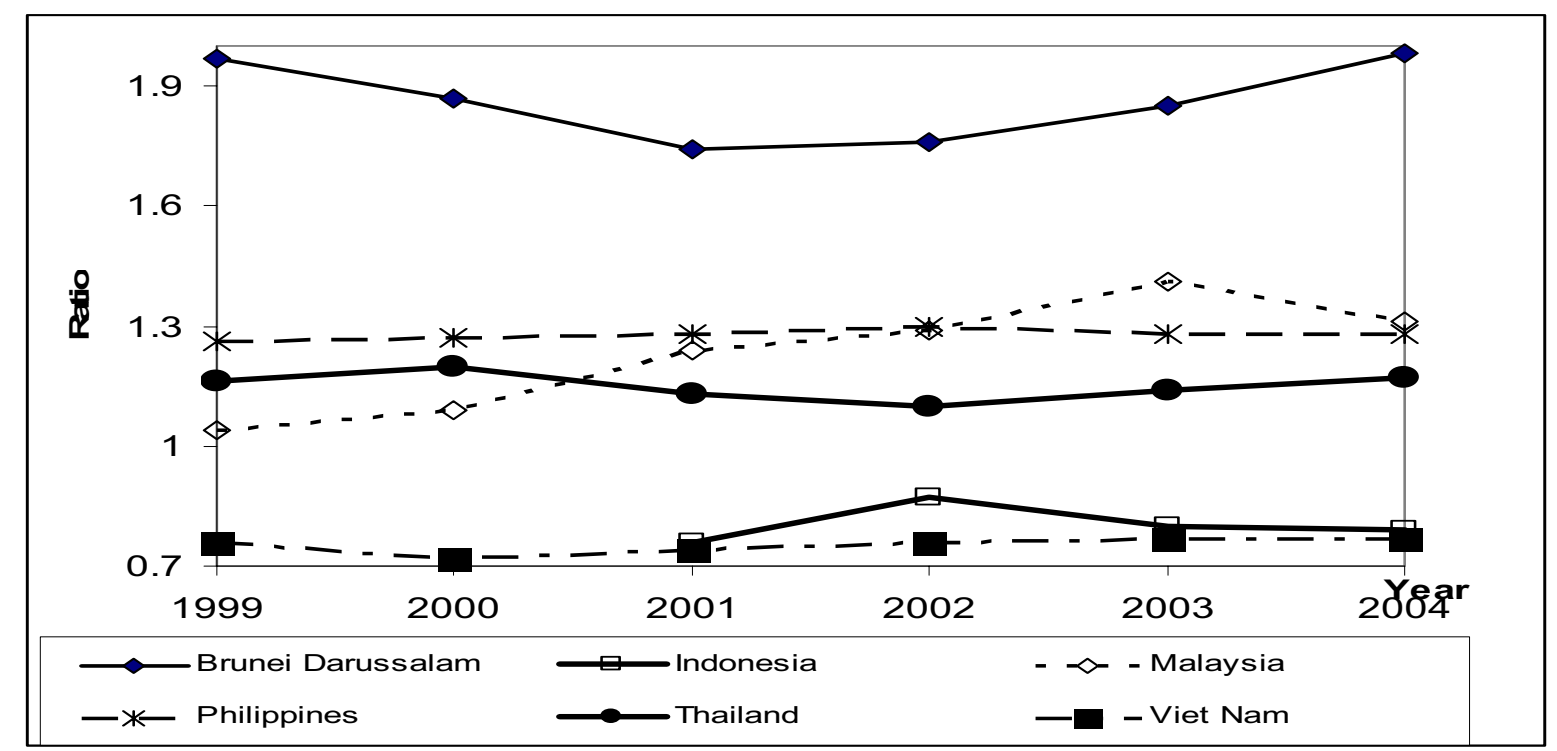

Figure 1. Tertiary Level Enrollment: Girls to Boys Ratio (ASEAN)

\section{Source: UN}

Note: Values more than 1 indicate, girls are more than boys 